\title{
PHENOLIC COMPOUNDS AND PROPERTIES OF ANTIOXIDANTS IN GRAPEVINE ROOTS (VITIS VINIFERA L.) UNDER DROUGHT STRESS FOLLOWED BY RECOVERY
}

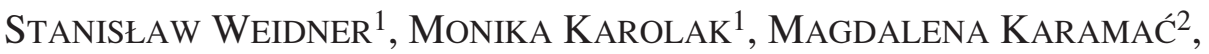 \\ AGNIESZKA KOSIŃSKA ${ }^{2}$, RYSZARD AMAROWICZ ${ }^{2}$ \\ ${ }^{1}$ Department of Biochemistry, Faculty of Biology, \\ University of Warmia and Mazury in Olsztyn \\ M. Oczapowskiego 1A, 10-957 Olsztyn-Kortowo, Poland \\ e-mail: stanislaw.weidner@uwm.edu.pl \\ 2 Division of Food Science, \\ Institute of Animal Reproduction and Food Research of Polish Academy of Sciences \\ Tuwima 10, Box 55, 10-718 Olsztyn 5, Poland
}

(Received: January 29, 2009. Accepted: March 18, 2009)

\begin{abstract}
Grapevine seedlings Vitis vinifera were grown in a greenhouse under optimum conditions (soil moisture ca $70 \%$ ) and under drought stress (soil moisture ca 35\%). In addition, some of the plants subjected to drought underwent subsequent regeneration under optimum conditions. Drought stress caused accumulation of total phenolic compounds in grapevine roots, which may indicate that these compounds play an important role in the adaptation of roots to growth under stress conditions. Phenolic acids found in the roots occurred in the ester-bound form only. $p$-coumaric acid was present in the highest concentrations (6.2 to $10.5 \mu \mathrm{g} / \mathrm{g}$ fresh matter). The content of ferulic acid was lower, ranging from 2.4 to $4.6 \mu \mathrm{g} / \mathrm{g}$ fresh matter. The lowest concentration in grapevine roots was achieved by caffeic acid (2.4 to $2.9 \mathrm{\mu g} / \mathrm{g}$ fresh matter). The levels of $p$-coumaric and ferulic acids in roots rose significantly under the drought stress, while the concentration of caffeic acid increased during the post-drought recovery period. This may suggest that some of the phenolic acids protect plants under stress conditions. All the extracts from grapevine roots had antioxidative properties, but the antiradical activity of the extracts obtained from roots subjected to drought stress was inferior to the control. The same extracts were also characterised by depressed reducing power. The results imply that tolerance of grapevine to soil drought may be associated with the value of antioxidative potential in root tissues of these plants.
\end{abstract}

KEY WORDS: antioxidant system, oxidative stress, drought stress, grapevine roots, phenolic compounds.

\section{INTRODUCTION}

Water deficit, extreme temperatures and excessive salinity may cause oxidative stress in plants. In order to avoid it, plants have developed a complex system of antioxidative defence, which can be regulated depending on the environmental conditions. Under non-stress conditions, the system itself is enough to maintain homeostasis of oxygenation and reduction reactions, which prevents oxidative damage to bio-particles. Excess of reactive oxygen species and free radicals generated by oxidative stress can be neutralized by plants in a number of ways. One possible defence mechanism involves scavenging systems, such as superoxide dismutase as well as catalyse and peroxidase. Another system employs small molecule compounds, such as glutathione, ascorbate, carotenoids, flavonoids, tocopherols, phenols, proline, etc., for neutralisation of reactive oxygen species and free radicals. Depending on the type of stress and affected organ, plants can activate different antioxidative mechanisms. It should be noted here that scavenging systems can be an important element of the processes which condition plant tolerance to stress (Qureshi et al. 2007; Weidner et al. 2007; Woźny and Przybył 2007).

Among various compounds present in plant tissues, phenolic acids and flavonoids have antioxidative properties (Sokół-Łętowska 1997; Sokół-Łętowska and Oszmiański 1998; Rosicka-Kaczmarek 2004). The extent of antioxidative effects produced by phenols largely depends on the structure of a given compound and especially on the number and distribution of hydroxyl groups (-OH) (Sokót-Łętowska and Oszmiański 1998). Antioxidative activity is much higher when a compound has two -OH groups in the ortho position, e.g. caffeic acid (Oszmiański 1995; Rosicka-Kaczmarek 2004). 
Phenolic compounds relatively easily release the $-\mathrm{OH}$ group hydrogen atom, which means that they oxidize themselves, thus acting as antioxidants. They reduce oxides and hydroxoides, and form complexes with metals (Oszmiański 1995; Sokół-Łętowska 1997; Sokół-Łętowska and Oszmiański 1998). Having released the hydrogen atom, phenols change into chinons, which are stabilized by non-pair electrons in the benzene ring, which means they cannot react with oxygen (Rosicka-Kaczmarek 2004). It is much more difficult to notice the dependence between antioxidative activity and the number and position of substitutents in the case of falvonoids (Oszmiański 1995; Sokó1Łętowska 1997; Sokół-Łętowska and Oszmiański 1998; Rosicka-Kaczmarek 2004).

The aim of the study has been to investigate the quantitative and qualitative modifications of phenolic compounds and to study the antioxidational abilities and the reducing power of extracts of grapevine roots which occur under the soil drought stress and following recovery.

\section{MATERIAL AND METHODS}

\section{Plants}

The material for the study consisted of whole root systems of grapevine Vitis vinifera, cultivar Himrod. The seedlings from which the roots were obtained had been purchased from a plant nursery in Jabłonowo (Poland).

\section{Plant growth conditions}

The seedlings were transferred into larger pots and grown for the next 8 weeks in a greenhouse under the following conditions: soil moisture ca $70 \%, 27 / 18^{\circ} \mathrm{C}$ day/night cycle and $14 \mathrm{~h}$ photoperiod at $180-200 \mu \mathrm{m} /\left(\mathrm{m}^{2} \mathrm{~s}\right)$ irradiance. During the whole period, the plants were regularly watered to maintain the optimum soil moisture (70\%). The soil moisture was monitored using a VP-PRL-Nr 279462 moisture meter manufactured by Mera. When the plants reached the expected size, the tests began. The plants were divided into four groups: control 1 (C1), drought stress (S), control $2(\mathrm{C} 2)$ and stress + regeneration after the stress period $(\mathrm{S}+\mathrm{R})$. The experimental conditions were as follows: $\mathrm{C} 1$ - plants were grown under optimum conditions for a week (soil moisture about $70 \%$ ), S - plants were grown under drought stress for a week (soil moisture kept down to about 35\%), C2 - plants were grown for two weeks under optimum conditions (soil moisture $70 \%$ ), $\mathrm{S}+\mathrm{R}$ - plants were grown for one week under drought stress (ca 35\% soil moisture) and afterwards, for another week, under optimum conditions (soil moisture ca 70\%).

When the experiment had terminated, the seedlings were removed from the pots and the roots were cleaned from soil by rinsing with room temperature water. Next, the whole root systems were incised. The incised roots were frozen in liquid nitrogen, lyophilized and fragmented in a mixer mill.

\section{Extraction of phenolic compounds}

Phenolic compound were extracted under nitrogen from roots three times into $80(\mathrm{w} / \mathrm{v})$ acetone for $15 \mathrm{~min}$ at $80^{\circ} \mathrm{C}$, as described by Amarowicz et al (1995). After evaporating the organic solvent in a rotary evaporator at $45^{\circ} \mathrm{C}$, the remaining aqueous solution was lyophilized.

\section{Determination of total phenolics}

The content of total phenolic compounds in the extracts was determined using the Folin-Ciocalteau's reagent (Naczk and Shahidi 1989) and (+)-catechin was used as a standard.

\section{Separation and analysis of phenolic acids by HPLC}

Phenolic acids (free and those liberated from soluble esters and from soluble glycosides) were isolated from the extracts according to the method previously described by Krygier et al. (1982), Zadernowski and Kozłowska (1993), and Weidner et al. (2000). An aqueous suspension of the methanolic extract $(200 \mathrm{mg}$ in $20 \mathrm{ml}$ ) was adjusted to $\mathrm{pH} 2$ with $6 \mathrm{M} \mathrm{HCl}$, and free phenolic acids were extracted five times into $20 \mathrm{ml}$ diethyl ether using a separatory funnel. The ether extract was evaporated to dryness under vacuum at room temperature. The water solution was neutralized and then lyophilized. The residue was dissolved in $20 \mathrm{ml}$ of $2 \mathrm{M} \mathrm{NaOH}$ and hydrolysed for $4 \mathrm{~h}$ under a nitrogen atmosphere at room temperature. After acidification to $\mathrm{pH} 2$ using $6 \mathrm{M} \mathrm{HCl}$, phenolic acids released from soluble esters were extracted from the hydrolysate five times into $30 \mathrm{ml}$ diethyl ether. Nine $\mathrm{ml}$ of $6 \mathrm{M} \mathrm{HCl}$ were added to the water solution, which was then placed in nitrogen atmosphere and hydrolysed for $1 \mathrm{~h}$ in a boiling water bath. Phenolic acids released from soluble glycosides were separated from the hydrolysate five times into $45 \mathrm{ml}$ diethyl ether. After ether evaporation, the dry residue was dissolved in $2 \mathrm{ml}$ methanol and filtered through a $0.45 \mu \mathrm{m}$ nylon filter. The sample was injected onto an HPLC column. A Shimadzu HPLC system was employed: LC - 10 ADVP pump, photodiode array detector UV-VIS SPD - M10AVP, oven CTO - 10 ASVP, Controller SCL - 10AVP. The conditions of the separations were as follows: pre-packed LUNA $\mathrm{C}_{18}$ column ( $5 \mu \mathrm{m}, 4.6 \times 250 \mathrm{~mm}$; Phenomenex); mobile phase water-acetonitrile - acetic acid (88:10:2, v/v/v) (Amarowicz and Weidner 2001); flow rate of $1 \mathrm{ml} \cdot \mathrm{min}^{-1}$; injection volume of $20 \mu \mathrm{l}$; the detector was set at 280 and $320 \mathrm{~nm}$; oven temperature was $20^{\circ} \mathrm{C}$.

\section{Determination of tannins with the vanillin method}

The content of tannins in the extract was determined using the modified Vanillin Assay (Price et al. 1978). Results were expressed as absorbance units at $500 \mathrm{~nm}$ per $\mathrm{mg}$ of extract $\left(\mathrm{A}_{500} / \mathrm{mg}\right)$. Briefly, to $0.5 \mathrm{ml}$ of extract, $2.5 \mathrm{ml}$ of solution B (obtained by dissolving $0.5 \mathrm{~g}$ of vanillin in 100 $\mathrm{ml}$ of solution A) was added. Solution A was made by adjusting $4 \mathrm{ml}$ of concentrated $\mathrm{HCl}$ to $100 \mathrm{ml}$ with methanol. The samples were left in the dark at room temperature for $20 \mathrm{~min}$, and then absorbance was measured at $500 \mathrm{~nm}$.

\section{Determination}

\section{of tannins using the protein precipitation method}

The content of tannins in the extract was determined using the method described by Hagerman and Butler (1978). Briefly, $2 \mathrm{ml}$ of bovine serum albumin (BSA) solution (concentration $1 \mathrm{mg} \cdot \mathrm{ml}^{-1}$ in $0.2 \mathrm{M}$ acetate buffer at $\mathrm{pH}$ 5.5 containing $0.17 \mathrm{M} \mathrm{NaCl}$ ) was added to $1 \mathrm{ml}$ of the extract. The sample was left for $15 \mathrm{~min}$ at room temperature and then centrifuged $(5000 \times \mathrm{g})$. After $15 \mathrm{~min}$ of centrifugation, the supernatant was removed and the pellet was washed with $1 \mathrm{~mL}$ acetate buffer and centrifuged again $(5000 \times \mathrm{g} / 15 \mathrm{~min})$. The sediment was dissolved in $4 \mathrm{~mL}$ of 
solution containing: $1 \%$ SDS and 5\% TEA, and $1 \mathrm{ml}$ of $0.01 \mathrm{M} \mathrm{FeCl}_{3}$ in $0.01 \mathrm{M} \mathrm{HCl}$ was added. The samples were left for $30 \mathrm{~min}$ at room temperature and the absorbance was measured at $510 \mathrm{~nm}$. The results were expressed as absorbance units at $510 \mathrm{~nm}$ per $1 \mathrm{mg}$ of extract $\left(\mathrm{A}_{510} / \mathrm{mg}\right)$.

\section{Antiradical activity of roots extracts}

The antiradical activity was analyzed with the method described by Yen and Chien (1995). Briefly, 0.1-0.5 mg of an extract dissolved in $0.1 \mathrm{ml}$ of methanol was added to 2 $\mathrm{ml}$ of methanol; then, $0.25 \mathrm{ml}$ of a DPPH (2,2-diphenyl-1-picrylhydrazyl) solution in the concentration of $1 \mathrm{mg} \cdot \mathrm{ml}^{-1}$ methanol was added. The mixture was left in the dark at room temperature for $20 \mathrm{~min}$. After that time, absorbance was read at a wavelength of $517 \mathrm{~mm}$. The analysis was performed in three replications.

\section{Reducing power of extracts}

Reducing power of phenolics present in the extracts was determined using the method described by Yen and Chen (1995). Briefly, $1 \mathrm{ml}$ of water containing 0.1-0.5 mg of an extract was pipetted into a tube. Next, $2.5 \mathrm{ml}$ of $0.2 \mathrm{M}$ phosphate buffer, $\mathrm{pH} 6.6$, and $2.5 \mathrm{ml}$ of $1 \%$ solution of potassium ferrocyanide were added. The mixture was incubated in a water bath at $50^{\circ} \mathrm{C}$ for $20 \mathrm{~min}$. Afterwards, $2.5 \mathrm{ml}$ of 10\% TCA (trichloroacetic acid) solution was added. To 2.5 $\mathrm{ml}$ of this sample, $2.5 \mathrm{ml}$ of $0.1 \% \mathrm{FeCl}_{3}$ in distilled water were added. After $10 \mathrm{~min}$ absorbance was measured at a wavelength of $700 \mathrm{~nm}$. The analysis was performed in three replications, and means for the values thus obtained were derived.

\section{Total Antioxidant Activity (TAA)}

The Total Antioxidant Activity of the extracts was determined according to the Trolox equivalent antioxidant activity (TEAC) assay described by Re et al. (1999). TAA was expressed as mmol Trolox equivalent/g of extract.

\section{Statistical evaluation}

All experiments were repeated four times, with three replications for each sample. The presented values are the means of twelve determinations \pm SD. Statistically significant differences in the mean values were tested by Student's $t$-test.

\section{RESULTS}

\section{Dry matter content}

The highest dry matter content was determined in roots of grapevine plants which had grown under strong drought stress (S sample), where it reached $22.7 \%$, being significantly higher than in the control sample C1 (14.9\%) (Table 1). In the roots of plants which had undergone drought stress followed by recovery $(\mathrm{S}+\mathrm{R}$ sample), the dry matter content (17.7\%) was lower than in the S sample but similar to that found in the $\mathrm{C} 2$ sample $(16.4 \%)$.

\section{Phenolic compounds}

The total concentration of phenolic compounds in extracts from grapevine roots was determined using a reaction with Folin-Ciocalteau's reagent. The results are illustrated in Table 2. The highest level of phenolic compo-
TABLE 1. The content of dry weight in grapevine roots after drought stress and recovery. Symbols of samples, C1, C2, S and S+R, are explained explained in Material and methods. Asterisks denote differences assessed by $t$-Student's test as significant at $p<0.05(*), p<0.01$ (**) and $p<0.001(* * *)$.

\begin{tabular}{cl}
\hline Sample & Dry weight content $(\%)$ \\
\hline $\mathrm{C} 1$ & $14.89 \pm 0.31$ \\
$\mathrm{~S}$ & $22.67 \pm 0.56(*)$ \\
$\mathrm{C} 2$ & $16.41 \pm 0.31$ \\
$\mathrm{~S}+\mathrm{R}$ & $17.71 \pm 0.47$ \\
\hline
\end{tabular}

TABLE 2. Comparison of the total phenolic content in grapevine roots after drought and recovery. Symbols of samples, C1, S, C2 and S+R, are explained in Material and methods. Asterisks denote differences assessed by $t$-Student's test as significant at $p<0.05(*), p<0.01(* *)$ and $p<0.001$ $(* * *)$.

\begin{tabular}{cl}
\hline Sample & \multicolumn{1}{c}{$\mathrm{mg} / \mathrm{g} \mathrm{FW}$} \\
\hline $\mathrm{C} 1$ & $9.57 \pm 0.06$ \\
$\mathrm{~S}$ & $15.72 \pm 0.09(* * *)$ \\
$\mathrm{C} 2$ & $13.31 \pm 0.15$ \\
$\mathrm{~S}+\mathrm{R}$ & $13.49 \pm 0.19$ \\
\hline
\end{tabular}

unds, $15.7 \mathrm{mg} / \mathrm{g}$ fresh weight, occurred in roots of grapevine plants which were subjected to drought stress (S). They contained much more phenolic compounds than roots of the control sample $(\mathrm{C} 1)-9.6 \mathrm{mg} / \mathrm{g} \mathrm{FW}$. The content of phenolic compounds in roots of the sample left to regenerate after a period of drought stress $(\mathrm{S}+\mathrm{R})$ was lower than in the $\mathrm{S}$ sample $(13.5 \mathrm{mg} / \mathrm{g} \mathrm{FW})$. The content of phenolic compounds in the sample $\mathrm{S}+\mathrm{R}$ was similar to that found in the sample C2 (13.3 mg/g FW).

\section{Content of tannins}

The content of tannins in roots of grapevine plants was analyzed with the Vanillin Assay and the BSA Precipitation Method (precipitation of tannins with protein). The vanillin assay is used to detect the presence of catechins and condensed tannins. The roots of grapevine plants which had been affected by drought stress (S), significantly more condensed tannins were found $\left(0.65 \mathrm{~A}_{500} / \mathrm{mg}\right.$ extract) versus the control sample $\left(\mathrm{C} 1 ; 0.56 \mathrm{~A}_{500} / \mathrm{mg}\right.$ extract $)$. Also the $\mathrm{S}+\mathrm{R}$ sample (drought stress followed by regeneration) contained much more condensed tannins $\left(0.75 \mathrm{~A}_{500} / \mathrm{mg}\right.$ extract) than the sample which had only undergone drought stress (S). The results are demonstrated in Table 3. The concentration of tannins in samples as determined by the BSA precipitation method can be seen in Table 4. This method is used to determine the presence of both condensed and hydrolyzing tannins. Samples S and C1 contained

TABLE 3. Comparison of the content of tannins in extracts of grapevine roots after drought stress and recovery according to the Vanillin Assay. Symbols of samples, C1, C2, S and S+R, are explained in Material and methods. Asterisks denote differences assessed by $t$-Student's test as significant at $p<0.05(*), p<0.01(* *)$ and $p<0.001$ (***).

\begin{tabular}{cl}
\hline Sample & $\mathrm{A}_{500} / \mathrm{mg}$ extract \\
\hline $\mathrm{C} 1$ & $0.56 \pm 0.02$ \\
$\mathrm{~S}$ & $0.65 \pm 0.02(* *)$ \\
$\mathrm{C} 2$ & $0.66 \pm 0.03$ \\
$\mathrm{~S}+\mathrm{R}$ & $0.75 \pm 0.02(* *)$ \\
\hline
\end{tabular}


TABLE 4. Comparison of the content of tannins in extracts of grapevine roots after drought stress and recovery according to the BSA precipitation method. Symbols of samples, C1, C2, S and S+R, are explained in Material and methods. Asterisks denote differences assessed by $t$-Student's test as significant at $p<0.05(*), p<0.01(* *)$ and $p<0.001(* * *)$.

\begin{tabular}{cl}
\hline Sample & $\mathrm{A}_{510} / \mathrm{mg}$ extract \\
\hline $\mathrm{C} 1$ & $0.294 \pm 0.005$ \\
$\mathrm{~S}$ & $0.291 \pm 0.003$ \\
$\mathrm{C} 2$ & $0.441 \pm 0.006$ \\
$\mathrm{~S}+\mathrm{R}$ & $0.387 \pm 0.011(*)$ \\
\hline
\end{tabular}

TABLE 5. Content of ester-bound $p$-coumaric acid in extracts of grapevine roots after drought stress and recovery. Symbols of samples, C1, C2, $\mathrm{S}$ and $\mathrm{S}+\mathrm{R}$, are explained in Material and methods. Asterisks denote differences assessed by $t$-Student's test as significant at $p<0.05(*), p<0.01$ $(* *)$ and $p<0.001(* * *)$

\begin{tabular}{cc}
\hline Sample & $\mu \mathrm{g} / \mathrm{g} \mathrm{FW}$ \\
\hline $\mathrm{C} 1$ & $6.22 \pm 0.11$ \\
$\mathrm{~S}$ & $10.53 \pm 0.22(* * *)$ \\
$\mathrm{C} 2$ & $9.94 \pm 0.25$ \\
$\mathrm{~S}+\mathrm{R}$ & $9.23 \pm 0.21(*)$ \\
\hline
\end{tabular}

comparable levels of these two types of compounds $(0.291$ and $0.294 \mathrm{~A}_{510} / \mathrm{mg}$ extract, respectively). During the regeneration period, tannins were observed to have increased in number, reaching the value of $0.39 \mathrm{~A}_{510} / \mathrm{mg}$ extract. The highest concentration of these compounds was found in the roots from the $\mathrm{C} 2$ sample $\left(0.44 \mathrm{~A}_{510} / \mathrm{mg}\right.$ extract $)$. It should be noted here that the amount of condensed tannins in the $\mathrm{S}+\mathrm{R}$ sample $\left(0.39 \mathrm{~A}_{510} / \mathrm{mg}\right.$ extract $)$ was much lower than in the $\mathrm{C} 2$ sample.

\section{Content of phenolic acids}

The qualitative assays of the grapevine root extracts enabled us to determine that they contained $p$-coumaric, ferulic and caffeic acids. All these phenolic acids occurred in the roots in the ester-bound form; no free and glycosidebound phenolic acids were discovered in the root extracts. The content of $p$-coumaric acid in the sample subjected to drought stress (S) was significantly higher than in the control (C1) (Table 5). The concentration of ester-bound $p$-coumaric acid in the $\mathrm{S}$ sample was 10.5 and in the $\mathrm{C} 1$ sample $-6.2 \mu \mathrm{g} / \mathrm{g}$ FW. During the recovery period following the drought, the amount of this acid in grapevine roots declined. The samples contained the following amounts of ester-bound $p$-cumaric acid: 9.2 in the $\mathrm{S}+\mathrm{R}$ sample and 9.9 $\mu \mathrm{g} / \mathrm{g} \mathrm{FW}$ in the $\mathrm{C} 2$ sample.

The content of ester-bound ferulic acid in grapevine roots was lower than that of $p$-coumaric acid, ranging from 2.4 to $4.6 \mu \mathrm{g} / \mathrm{g} \mathrm{FW}$. The highest content of this acid was found in the roots of plants subjected to drought stress (S) (Table 6). In this sample, $4.6 \mu \mathrm{g}$ ferulic acid/g FW was determined versus $2.4 \mu \mathrm{g} / \mathrm{g} \mathrm{FW}$ in the control sample (C1). While the plants regenerated after the stress, the amount of ester-bound ferulic acid in roots decreased. In the $\mathrm{S}+\mathrm{R}$ sample, its content went down to $3.8 \mu \mathrm{g} / \mathrm{g} \mathrm{FW}$, which was still significantly more than in the control sample C2 $(3.4 \mu \mathrm{g} / \mathrm{g} \mathrm{FW})$. The content of caffeic acid in grapevine roots was the lowest among all the three phenolic acids. It varied from 2.4 to $2.9 \mathrm{\mu g} / \mathrm{g} \mathrm{FW}$. The content of ester-bound caffeic acid in the control sample C1 was $2.4 \mu \mathrm{g} / \mathrm{g}$ FW. It
TABLE 6. Content of ester-bound ferulic acid in extracts of grapevine roots after drought stress and recovery. Symbols of samples, C1, C2, S and $\mathrm{S}+\mathrm{R}$, are explained in Material and methods. Asterisks denote differences assessed by $t$-Student's test as significant at $p<0.05(*), p<0.01(* *)$ and $p<0.001$ (***).

\begin{tabular}{cl}
\hline Sample & \multicolumn{1}{c}{$\mu \mathrm{g} / \mathrm{g} \mathrm{FW}$} \\
\hline $\mathrm{C} 1$ & $2.44 \pm 0.05$ \\
$\mathrm{~S}$ & $4.63 \pm 0.09(* * *)$ \\
$\mathrm{C} 2$ & $3.42 \pm 0.07$ \\
$\mathrm{~S}+\mathrm{R}$ & $3.84 \pm 0.13(* *)$ \\
\hline
\end{tabular}

TABLE 7. Content of ester-bound caffeic acid in extracts of grapevine roots after drought stress and recovery. Symbols of samples, C1, C2, S and $\mathrm{S}+\mathrm{R}$, are explained in Material and methods. Asterisks denote differences assessed by $t$-Student's test as significant at $p<0.05(*), p<0.01(* *)$ and $p<0.001(* * *)$

\begin{tabular}{cl}
\hline Sample & $\mu \mathrm{g} / \mathrm{g} \mathrm{FW}$ \\
\hline $\mathrm{C} 1$ & $2.41 \pm 0.05$ \\
$\mathrm{~S}$ & $2.54 \pm 0.06$ \\
$\mathrm{C} 2$ & $2.71 \pm 0.07$ \\
$\mathrm{~S}+\mathrm{R}$ & $2.92 \pm 0.06(*)$ \\
\hline
\end{tabular}

tended to increase slightly in the samples under drought stress $(2.5 \mu \mathrm{g} / \mathrm{g}$ FW) but no significant differences were found between these two samples (Table 7). The amount of ester-bound caffeic acid was also observed to have risen in the roots of grapevine plants during the recovery period after drought stress (sample S+R; 2.9 $\mu \mathrm{g} / \mathrm{g} \mathrm{FW}$ ).

\section{$D P P H^{\bullet}$ free radical scavenging capability of extracts}

Aqueous solution of a DPPH* (2,2-diphenyl-1-picrylhydrazyl) free radical is deep red in colour. Under the effect of antioxidants found in extracts, this radical becomes paler so that eventually a colourless product is obtained. As a result of this reaction the absorbance of the solution decreases. The higher the content of antioxidants in a solution, the paler the solution. A $\mathrm{DPPH}^{*}$ solution shows the maximum absorbance at a wavelength of $517 \mathrm{~nm}$. The results of our assays are presented in Figure 1. All the analysed extracts proved to be capable of scavenging a $\mathrm{DPPH}^{-}$ free radical. The highest scavenging capacity was demonstrated by the most concentrated solutions. The sample subjected to drought stress (S) was less capable of scavenging a $\mathrm{DPPH}^{*}$ free radical than the control sample $\mathrm{C} 1$. The absorbance measured at a wavelength of $517 \mathrm{~nm}$ for the $\mathrm{S}$ sample, at the extract concentration of $0.04 \mathrm{mg}$ per sample, was 0.42 , whereas an analogous measurement for the C1 sample was 0.34 . This seems to suggest that under drought stress the quantities of antioxidants in roots tend to decline. In the $\mathrm{S}+\mathrm{R}$ sample, the absorbance was identical to that in the $\mathrm{C} 1$ sample $(0.34)$, while the lowest absorbance was detected in the $\mathrm{C} 2$ sample (0.27).

\section{Reducing power of the extracts}

Under the influence of the reducing power of the extracts, $\mathrm{Fe}^{3+}$ ions were reduced to $\mathrm{Fe}^{2+}$ ions, and the colour of the reaction mixture changed from yellow to various tints of blue and green. The content of the reduced $\mathrm{Fe}^{2+}$ ions was measured by analysing the amount of Prussian blue produced in the solution, using absorbance measurements at a $700 \mathrm{~nm}$ wavelength. The results are shown in 


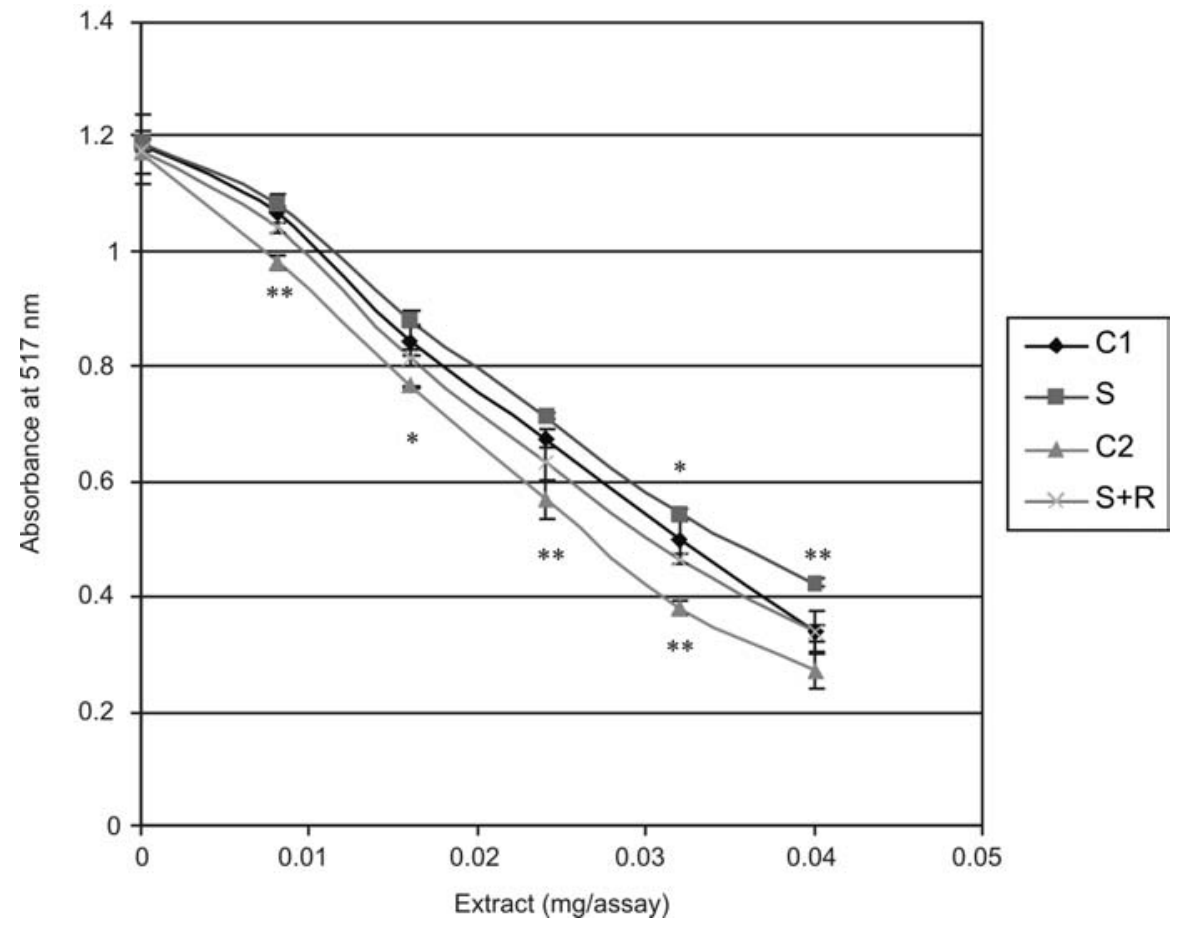

Fig. 1. Scavenging effects of extracts of grapevine roots after drought stress and recovery on $\mathrm{DPPH}^{\cdot}$. Symbols of samples, $\mathrm{C} 1, \mathrm{C} 2$, $\mathrm{S}$ and $\mathrm{S}+\mathrm{R}$, are explained in Material and methods. Vertical lines denote standard deviation. Asterisks denote differences assessed by $t$-Student's test as significant at $p<0.05\left(^{*}\right), p<0.01(* *)$ and $p<0.001(* * *)$.
Figure 2. All the samples revealed reducing properties. The sample exposed to drought stress (S) was characterized by a much weaker reducing power than the $\mathrm{C} 1$ sample. Regarding the $\mathrm{S}$ and $\mathrm{C} 1$ samples, significant differences occurred at three extract concentrations: $0.4,0.6$ and $0.8 \mathrm{mg} / \mathrm{sample}$. Stronger reducing power than in the above samples was determined for the $\mathrm{S}+\mathrm{R}$ sample, while the $\mathrm{C} 2$ sample proved to possess the strongest reducing properties. At the extract concentration equal $0.8 \mathrm{mg} / \mathrm{sample}$, the absorbance for the samples $\mathrm{C} 1, \mathrm{~S}, \mathrm{C} 2$ and S+R was, respectively: 0.97, $0.92,1.21$ and 1.11 .

\section{Total antioxidant activity}

The ability to scavenge an $\mathrm{ABTS}^{+\bullet}-2,2^{\prime}$-Azino-bis (3ethylbenzothiazoline-6-sulfonic acid) free cation radical is presented in Table 8. The results which define the antioxidative capacity of the extracts are expressed in Trolox equivalents. A colour extract of an aqueous $\mathrm{ABTS}^{+\bullet}$ cation radical becomes colourless when a solution of the extract is added to it. The phenolic compounds from the extract have anti-radical properties, which means that they scavenge the cation radical $\mathrm{ABTS}^{+\bullet}$. The higher the scavenging capacity, and consequently the higher the concentration of antioxidants in the solution, the lighter the colour of the sample and the lower its absorbance measured at a $734 \mathrm{~nm}$ wavelength. All the analyzed samples proved that they were able to scavenge the cation radical $\mathrm{ABTS}^{+\cdot}$. The results can be seen in Table 8. Similarly to the previous research, the sample exposed to drought stress was significantly less capable of scavenging the radical (1.08) versus the control

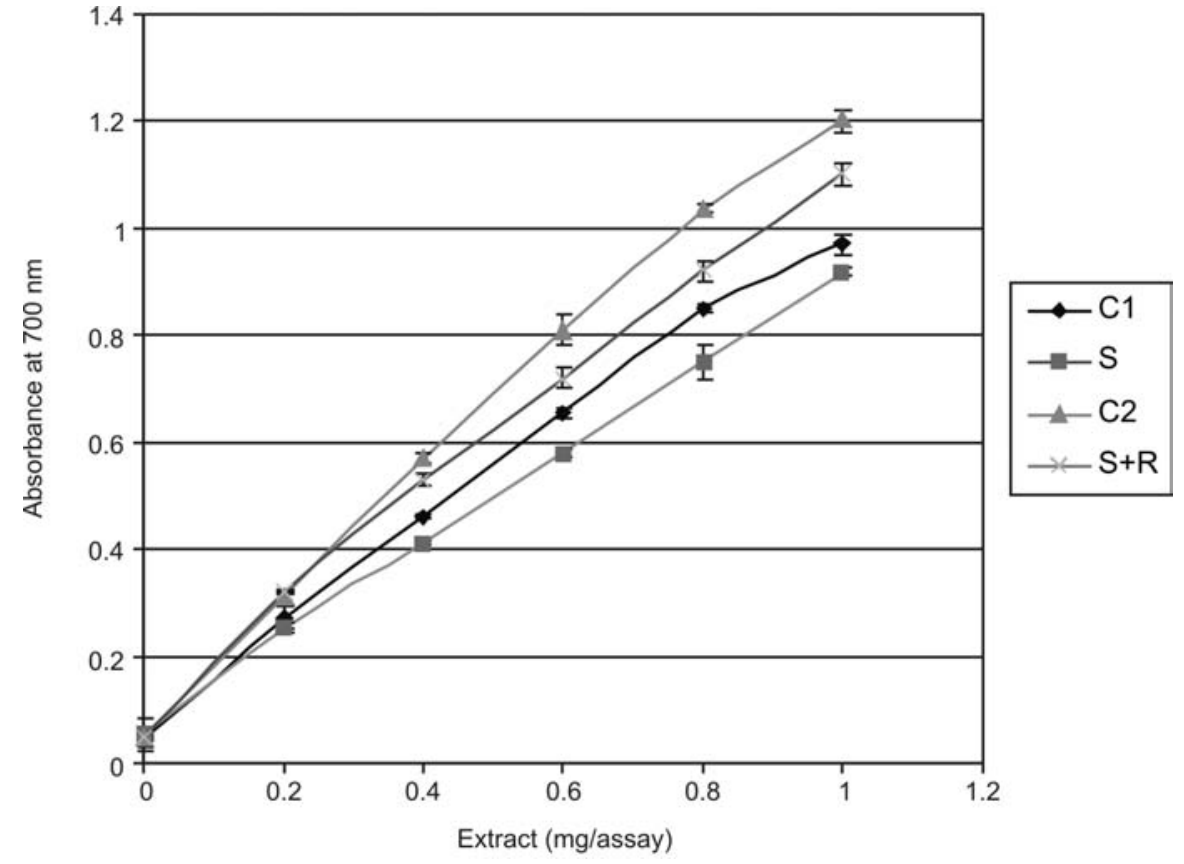

Fig. 2. Reducing power of extracts of grapevine roots after drought stress and recovery. Symbols of samples, C1, C2, S and S+R, are explained in Material and methods. Vertical lines denote standard deviation. Asterisks denote differences assessed by $t$-Student's test as significant at $p<0.05(*), p<0.01(* *)$ and $p<0.001$ (***). 
TABLE 8. Scavenging effects of extracts of grapevine roots after drought stress and recovery on $\mathrm{ABTS}^{+}{ }^{\circ}$. Symbols of samples, C1, C2, S and S+R, are explained in Material and methods. Asterisks denote differences assessed by $t$-Student's test as significant at $p<0.05(*), p<0.01(* *)$ and $p<0.001(* * *)$.

\begin{tabular}{cl}
\hline Sample & mmol of Trolox/g of extract \\
\hline $\mathrm{C} 1$ & $1.47 \pm 0.02$ \\
$\mathrm{~S}$ & $1.08 \pm 0.05(* *)$ \\
$\mathrm{C} 2$ & $1.30 \pm 0.04$ \\
$\mathrm{~S}+\mathrm{R}$ & $1.26 \pm 0.02(*)$ \\
\hline
\end{tabular}

sample C1 (1.47 nmol Trolox/g extract). The $\mathrm{S}+\mathrm{R}$ sample was more effective in scavenging the radical $(1.26 \mathrm{nmol}$ Trolox/g extract) than the $\mathrm{S}$ sample. The scavenging capability of the $\mathrm{C} 2$ sample in terms of the $\mathrm{ABTS}^{+}$radical was $1.30 \mathrm{nmol}$ Trolox/g extract.

\section{DISCUSSION}

Plant root systems are studied in many laboratories worldwide. Sowiński (2000), who examined maize, found out that growth of maize roots is strongly correlated with the temperature of the substratum. Richter et al. (1998) proved a relationship between the size of a root system in maize and accumulation of dry matter in its shoots. In turn, Hashimoto et al. (2004) showed that roots not only play an important role in the uptake of water and mineral salts from soil but also participate in plants' tolerance to many stresses, such as drought, high salinity and chill. Noteworthy is the fact that Xiong et al. (2006) developed new approaches to studying plant drought tolerance and identified the inhibition of lateral root development by drought stress as an adaptive response to the stress.

Numerous studies have revealed that environmental stresses often raise the accumulation of phenylopropanoids, which are believed to play a regulatory role in some metabolic processes (Dixon and Paiva 1995; Solecka 1997; Janas et al. 2000; Wróbel et al. 2005). Also the research presented in this paper has demonstrated that the total content of phenols strongly increases in grapevine roots under drought stress.

Using AIP (2-aminoindan-2-phosphonic amid), the strongest inhibitor of PAL (phenylalamine ammonia-lyase), Szafrańska et al. 2002 made it evident that PAL (E.C.4.3.1.5) is the main enzyme in the synthesis pathway of phenolic compounds. They proved that application of AIP to soybean roots causes a decline in the content of some derivatives of cinnamic and benzoic acids, as a result of which plants are less tolerant to chill stress. Their results have been confirmed by Janas et al. (1999), who additionally showed that AIP has some influence on other physiological processes which affect plants' tolerance to stress conditions.

The present study has revealed large changes in the composition of phenolic acids in grapevine roots drought stress. The levels of ester-bound $p$-coumaric and ferulic acids in roots rose significantly under the drought stress. Also some previous experiments have showed that the chilling stimulated increased accumulation of some phenolic compounds (free gallic acid and catechins) in germinating Vitis riparia seeds (Wróbel et al. 2005). Janas et al. (2000) demonstrated the presence of six phenolic acids in soybean roots: $p$-hydroxybenzoic, vanillic, syringic, anisic, $p$-coumaric and ferulic and during $24 \mathrm{~h}$ of low temperature exposure; also, an increase in the relative level of ester-boundsoluble phenolic acids occurred. It should be stressed that in plants subjected to cold and then to freezing treatments, the levels of $p$-coumaric, sinapic and ferulic acids increased about 3-, 4- and 5-fold, respectively (Solecka et al. 1999). Acclimation of plants in cold and the frost-thaw treatment resulted in the promotion of phenolic estrification. It can be added that hydroxycinnamoyl esters, present in cell vacuoles, may be used as substrate for vacuolar peroxidases in a peroxidase /phenolic/ ascorbate scavenging system which protect plant cells from the stress-induced oxidative damage due to increased production of active oxygen species (Solecka et al. 1999).

Anioxidant and antiradical activity of grape extracts has been investigated using several methods such as liposome system, a $\beta$-carotene-linoleate model system, lipid peroxidation, human LDL oxidation, serum total antioxidant activity, scavenging of $\mathrm{DPPH}^{\bullet}$ radical, the FRAP assay and the ORAC assay (Amarowicz and Weidner 2009). Significant correlation between the content of total phenolics and antioxidant activity was found (Alonso et al. 2002, Weidner et al. 2007). Heo et al. (2007) found that there was no synergistic effect in a model system among the phenolic studied. Only an additive effect of antioxidant capacity was observed.

Among plant organs, root tissue is severely affected by drought due to its direct contact with drying soil. Among the most common responses to water stress are electron leakage through tylakoid membranes, damage of chlorophylls, decrease in antioxidant systems, increase in production of $\mathrm{H}_{2} \mathrm{O}_{2}, \mathrm{O}^{-}$, lipid peroxidation and decrease in photosynthesis (Qureshi et al. 2007).

The above results suggest that all the extracts from grapevine roots had antioxidative properties, but the antiradical activity of the extracts obtained from roots subjected to drought stress was lower to the control. The same extracts were also characterized by depressed reducing power. Similar results had been obtained in our earlier studies on antioxidant properties of Vitis amurensis seeds under osmotic stress (Weidner et al. 2007). The extracts from seeds germinated under optimum conditions exhibited strong antiradical properties against the $\mathrm{DPPH}^{\bullet}$ radical as well as reducing power. As regards the extracts from grape seeds germinated under osmotic stress, this capability was much weaker. The research demonstrated that antioxidants could interfere with the oxidation process induced by various stresses by acting as oxygen scavengers, therefore the tolerance to drought stress might be correlated with an increase in the antioxidant potential.

\section{LITERATURE CITED}

ALONSO A.M., GUILLEN D.A., BARROSO C.G., PUERTAS B., GARCIA A. 2002. Determination of antioxidant activity of wine by products and its correlation with polyphenolic content. J. Agric. Food Chem. 50: 5832-5836.

AMAROWICZ R., PISKUA M., HONKE J., RUDNICKA B., TROSZYŃSKA A., KOZŁOWSKA H. 1995. Extraction of phenolic compounds from lentil seeds (Lens culinaris) with various solvents. Pol. J. Food Nutr. Sci. 4/45: 53-62. 
AMAROWICZ R., WEIDNER S. 2009. Biological activity of grapevine phenolic compounds. In: Grapevine Molecular Physiology \& Biotechnology, 2nd edn., K.A. Roubelakis-Angelakis (ed.), Springer Science + Business Media B.V. DOI 10.1007/978-90-481-2305-6_14.

AMAROWICZ R., WEIDNER S. 2001. Content of phenolic acids in rye caryopses determined using DAD-HPLC method. Czech J. Food Sci. 19: 201-203.

DIXON R.A., PAIVA N.L. 1995. Stress-induced Phenylpropanoid metabolism. Plant Cell 7: 1085-1097.

HAGERMAN A., BUTLER L. 1978. Protein precipitation method for quantitative determination of tannins. J. Agric. Food Chem. 26: 809-811.

HASHIMOTO M., KISSELEVA L., SAWA S., FUNEKAWA Y., KOMATSU S., KOSHIBA T. 2004. Novel rice PR10 protein, PSOsPR10 specifically induced in roots by biotic and abiotic stresses, possibly via the jasmonic acid signaling pathway. Plant Cell Physiol. 45: 550-559.

HEO H.J., KIM Y.J., CHUNG D., KIM D.O. 2007. Antioxidant capacities of individual and combined phenolics in a model system. Food Chem. 104: 87-92.

JANAS K.M., CVIKROVA M., PALĄGIEWICZ A., EDER J. 1999. Wpływ kwasu 2-aminoindan-2-fosfoniowego na zawartość fenoli po krótkiej ekspozycji korzeni soi na chłód. Zesz. Problem. Post. Nauk Rol. 496: 97-102. (in Polish)

JANAS K.M., CVIKROVA M., PAŁAGIEWICZ A., EDER J. 2000. Alternations in phenylpropanoid content in soybean roots during low temperature acclimation. Plant Physiol Biochem. 38: 587-593.

KRYGER K., SOSULSKI F.W., HOGGE L. 1982. Free, esterified, and insoluble-bound phenolic acids. 1. Extraction and purification procedure. J. Agric. Food. Chem. 30: 330-334.

NACZK M., SHAHIDI F. 1989. The effect of methanol-ammonia-water treatment on the content of phenolic acids of canola. Food Chem. 31: 15-164.

OSZMIAŃSKI J. 1995. Polifenole jako przeciwutleniacze w żywności. Przem. Spoż. 3: 94-96. (in Polish)

PRICE N.J., van SCOYOC S., BUTLER L.G. 1978. A critical evaluation of the vanillic reactions an assay for tannin in sorghum grain. J. Agric. Food Chem. 26: 1214-1218.

QURESHI M.J., QADIR S., ZOLLA L. 2007. Proteomic-based dissection of stress-responsive pathways in plants. J. Plant Physiol. 164: 1239-1260.

RE R., PELLEGRINI N., PROTEGGENTE A., PANNALA A., YANG M., RICE-EVANS C. 1999. Antioxidant activity applying an improved ABTS radical cation decolorization assay. Free Rad. Biol. Med. 26: 1231-1237.

RICHTER R., SOLDATI A., STERZINGER A., ZHANG L. 1998. Higher chilling tolerance in maize is not always related to the ability for greater and faster abscisic acid accumulation. J. Plant Physiol. 153: 154-162.
ROSICKA-KACZMAREK J. 2004. Polifenole jako naturalne antyoksydanty w żywności. Przegl. Piek. Cuk. 6: 12-16. (in Polish)

SOKÓŁ-ŁĘTOWSKA A. 1997. Próby opracowania i zastosowania preparatów związków fenolowych wybranych surowców roślinnych jako przeciwutleniaczy. Zesz. Nauk. AR we Wrocławiu. Techn. Żywn. 319: 99-117. (in Polish)

SOKÓŁ-ŁETOWSKA A., OSZMIAŃSKI J. 1998. Właściwości przeciwutleniające naturalnych polifenoli. Zesz. Nauk. AR we Wrocławiu. Techn. Żywn. 328: 73-83. (in Polish)

SOLECKA D., BOUDET A.M., KACPERSKA A. 1999. Phenylpropanoid and anthocyanin changes in low-temperature treated winter oilseed rape leaves. Plant Physiol. Biochem. 37: 491-496.

SOLECKA D. 1997. Role of phenylolopropanoid compounds in plant response to different stress factors. Acta Physiol. Plant. 19: $257-268$

SOWIŃSKI P. 2000. Wrażliwość kukurydzy na chłód. Część II. System korzeniowy, regulacja funkcjonowania rośliny, perspektywy hodowli. Biuletyn IHAR. 214: 17-29. (in Polish)

SZAFRAŃSKA K., POSMYK M., JANAS K.M. 2002. Aktywność amoniakoliazy L-fenyloalaniny i zawartość fenoli rozpuszczalnych u dwóch odmian soi różniących się wrażliwością na chłód. Post. Nauk Rol. 481: 223-228. (in Polish)

WEIDNER S., AMAROWICZ R., KARAMAĆ M., FRĄCZEK E. 2000. Changes in endogenous phenolic acids during development of Secale cereale caryopses and after dehydration treatment of unripe rye grains. Plant Physiol. Biochem. 38: 595-602.

WEIDNER S., KARAMAĆ M., AMAROWICZ R., SZYPULSKA E., GOŁGOWSKA A. 2007. Changes in composition of phenolic compounds and antioxidant properties of Vitis amurensis seeds germinated under osmotic stress. Acta Physiol. Plant. 29: 283-290.

WOŹNY A., PRZYBYŁ K. 2007. Komórki roślinne w warunkach stresu. Wyd. Naukowe UAM w Poznaniu. (in Polish)

WRÓBEL M., KARAMAĆ M., AMAROWICZ R., FRĄCZEK E., WEIDNER S. 2005. Metabolism of phenolic compounds in Vitis riparia seeds during stratification and during germination under optimal and low temperature stress conditions. Acta Physiol. Plant. 27: 313-320.

XIONG L., WANG R.G., MAO G., KOCZAN J.M. 2006. Identification of drought tolerance determinants by genetic analysis of root response to drought stress and abscisic acid. Plant Physiol. 142: 1065-1074.

YEN G.-C., CHEN H.-Y. 1995. Antioxidant activity of various tea extracts in relation to their antimutagenicity. J. Agric. Food Chem. 43: 27-32.

ZADERNOWSKI R., KOZŁOWSKA H. 1983. Phenolic acids in soybean and rapeseed flours. Lebensm. Wiss. Technol. 16: 110-114. 